\title{
EFIKASI DIRI AKADEMIK DALAM MENGHADAPI TUNTUTAN PERKULIAHAN PADA MAHASISWA
}

\author{
Evie Syalviana \\ Institut Agama Islam Negeri Sorong \\ eviesyalviana1990@gmail.com
}

\begin{abstract}
The challenges of students in dealing with the teaching and learning process are quite diverse, so there are also various ways of handling these students to deal with them. How to handle challenges in the teaching and learning process requires a positive concept of academic self-efficacy. This research is qualitative research with data collection tools using observation and interviews. Observation and interview guides are made according to aspects of the target behavior, namely level, breadth, and strength. Based on the results of the study, it shows that the subject has high self-efficacy in the field of science that is currently being undertaken. This can be seen in the seriousness of the subject towards the lecture materials and the efforts of the subject in dealing with difficulties in lecture assignments. Subjects have a high level of self-confidence in carrying out assignments in lectures. For the subject, although there are many difficulties in doing these tasks, the subject has high confidence to always be able to do the given task.
\end{abstract}

Keywords: Academic self-efficacy, Students

\begin{abstract}
ABSTRAK
Tantangan mahasiswa dalam menghadapi proses belajar mengajar cukup beragam sehingga beragam pula cara penanganan mahasiswa tersebut untuk menghadapinya. Cara penanganan tantangan dalam proses belajar mengajar membutuhkan konsep efikasi diri akademik yang positif. Penelitian ini merupakan penelitian kualitatif dengan alat pengumpulan data menggunakan observasi dan wawancara. Panduan observasi dan wawancara dibuat sesuai dengan aspek dari target perilaku yaitu level, keluasan dan kekuatan. Berdasarkan hasil penelitian menunjukkan bahwa subjek memiliki efikasi diri yang tinggi terhadap bidang ilmu yang dijalani saat ini. Hal tersebut nampak pada keseriusan subjek terhadap materi-materi kuliah dan upaya-upaya subjek dalam menghadapi kesulitan pada tugas-tugas kuliah. Subjek memiliki tingkat keyakinan diri yang tinggi pada pengerjaan tugas di perkuliahan. Bagi subjek walau terdapat banyak kesulitan dalam mengerjakan tugas-tugas tersebut, namun subjek memiliki keyakinan yang tinggi untuk selalu mampu mengerjakan tugas yang diberikan.
\end{abstract}

Kata kunci: Efikasi diri akademik, Mahasiswa 


\section{PENDAHULUAN}

Mahasiswa merupakan sebuah identitas yang tidak mudah untuk dijalani. Ada banyak tuntutan akademik saat memilih untuk menjadi seorang mahasiswa. Tuntutan akademik tersebut tentu diimbangi dengan keyakinan diri (self-efficacy), motivasi, dan konsep diri individu dengan baik.

Sebuah penelitian yang dilakukan oleh Schunk dan Pajares (2012) menunjukkan bahwa self-efficacy individu cenderung menurun sebagai mahasiswa yang disebabkan oleh beberapa faktor, yaitu adanya kompetisi yang semakin besar antar mahasiswa, sistem penilaian yang mengacu pada norma, perhatian pengajar yang semakin berkurang, dan adanya tekanan transisi sekolah. Sehingga perlu adanya pemahaman tentang pentingnya keyakinan diri terutama pada saat ada tantangan akademis yang sangat mudah melemahkan efikasi diri individu.

Konsep efikasi diri merupakan kemampuan seseorang dalam mengatur sebuah mekanisme kognitif yang berfungsi untuk sebuah persepsi, evaluasi, dan pengaturan perilaku. Sebuah penelitian menunjukkan bahwa individu yang berperan dalam lingkup akademik dapat memiliki nilai self-efficacy academic yang tinggi karena individu memiliki fokus pada persyaratan tugas, kurangnya tingkat kecemasan yang pada kinerja kognisi (Bandura, dalam Schunk \& Pajares, 2012). Keluhan yang terdengar dari beberapa mahasiswa tentang tuntutan akademik seperti pemberian tugas, sistem perkuliahan sangatlah lazim untuk diamati. Tidak sedikit pula mahasiswa mampu menghadapi tantangan tersebut dengan baik. Salah satu penyebab keragaman coping pada mahasiswa saat menghadapi tantangan akademik tersebut adalah tingkat efikasi diri akademik mahasiswa.

Schunk dan Pajares menjelaskan dalam penelitiannya bahwa pelajar dengan efikasi diri yang tinggi mampu menyelesaikan masalah penampilan pemantauan kinerja yang lebih besar dan akan lebih bertahan lebih lama dibanding dengan mahasiswa yang memiliki efikasi diri yang rendah. Oleh karena itu, efikasi diri akademik memiliki korelasi positif terhadap tujuan mahasiswa dalam mencapai prestasi, kepuasan nilai potensial dan pencapaian aktual. Adanya korelasi tersebut membuat penulis ingin melihat tingkat efikasi diri akademik mahasiswa yang sedang mengalami tuntutan akademik, dan sejauh mana keyakinan mahasiswa tersebut dalam melakukan coping terhadap tuntutan akademiknya. 


\section{Kajian teori}

1. Definisi Efikasi Diri Akademik Efikasi diri akademik merupakan keyakinan tentang kemampuan atau kompetensi yang dimiliki seseorang. Kemampuan tersebut dapat mengarahkan motivasi, kemampuan kognitif dan pengambilan tindakan. Hal tersebut diperlukan untuk mengerjakan tugas, mencapai tujuan dan mengatasi tantangan akademik (Bandura, dalam Schunk \& Pajares, 2012).

\section{Bong dan Skaalvik (2003)} menjelaskan bahwa self-efficacy mampu menjelaskan dan memprediksikan terhadap pikiran, emosi dan tindakan yang tingkat keberhasilannya dapat dilihat pada apa yang individu yakini. Keyakinan yang dimiliki tersebut membuat setiap individu percaya bahwa apa yang diinginkan dapat dicapai dalam situasi tertentu. Keyakinan tersebut memiliki hubungan yang signifikan perkembangan kognitif individu.

Efikasi diri akademik merupakan keyakinan individu terhadap keberhasilan dalam mengerjakan beberapa tugas akademik. Efikasi diri akademik mengacu pada persepsi seseorang tentang kompetensi yang dimiliki untuk melakukan classwork. Altunsoy et al (dalam, Turgut, 2013) menambahkan bahwa efikasi diri termasuk keyakinan tentang kemampuan untuk mencapai tugas akademik.

\section{Aspek-aspek Efikasi Diri}

Akademik

Bandura (dalam Schunk \& Pajares, 2012) mengemukakan bahwa keyakinan diri individu dapat dilihat dari tiga dimensi, yaitu:

a. Tingkat (level)

Keyakinan diri individu dalam mengerjakan suatu tugas berbeda dalam tingkat kesulitan tugas. Individu memiliki keyakinan diri yang tinggi pada tugas yang mudah dan sederhana, atau juga pada tugas-tugas yang rumit dan membutuhkan kompetensi yang tinggi. Individu yang memiliki keyakinan diri yang tinggi cenderung memilih tugas yang tingkat kesukarannya sesuai dengan kemampuannya.

\section{b. Keluasan (generality)}

Dimensi ini berkaitan dengan penguasaan individu terhadap bidang atau tugas pekerjaan. Individu dapat menyatakan dirinya memiliki keyakinan diri pada aktivitas yang luas, atau terbatas pada fungsi domain tertentu saja. Individu dengan keyakinan diri yang tinggi akan mampu menguasai beberapa bidang sekaligus untuk menyelesaikan suatu 
tugas. Individu yang memiliki keyakinan diri yang rendah hanya menguasai sedikit bidang yang diperlukan dalam menyelesaikan suatu tugas.

c. Kekuatan (strength)

Dimensi yang ketiga ini lebih menekankan pada tingkat kekuatan atau kemantapan individu terhadap keyakinannya. Keyakinan diri bahwa tindakan yang dilakukan akan memberikan hasil sesuai yang diharapkan individu menjadi dasar dirinya melakukan usaha yang keras, bahkan ketika menemui hambatan sekalipun.

\section{Faktor-faktor yang Mempengaruhi} Efikasi Diri Akademik

Terdapat beberapa faktor yang dapat mempengaruhi efikasi diri akademik seseorang, antara lain:

a. Peran gender

Sebuah penelitian menunjukkan bahwa anak laki-laki cenderung lebih percaya diri dibandingkan dengan anak perempuan, utamanya dalam lingkup akademis yang berhubungan dengan matematika, ilmu pengetahuan dan teknologi). Namun sebaliknya pada wilayah bidang seni dan bahasa, laki-laki dan perempuan memiliki kepercayaan yang sama dan fakta menunjukkan bahwa pencapaian perempuan lebih tinggi (Turgut, 2013).

b. Lingkungan sekolah

Sebuah penelitian yang dilakukan

oleh Schunk dan Pajares (2012) menunjukkan bahwa self-efficacy individu cenderung menurun sebagai mahasiswa yang disebabkan oleh beberapa faktor, yaitu adanya kompetisi yang semakin besar antar mahasiswa, sistem penilaian yang mengacu pada norma, perhatian pengajar yang semakin berkurang, dan adanya tekanan transisi sekolah.

\section{METODE PENELITIAN}

Metode penelitian yang digunakan adalah metode penelitian kualitatif. Adapun alat pengumpulan data yang digunakan adalah dengan metode observasi dan wawancara. Hasil observasi dan wawancara akan dianalisis

\section{HASIL DAN PEMBAHASAN}

1. Hasil observasi

Tujuan observasi pada asesmen ini adalah untuk mengetahui efikasi diri akademik yang tercermin dalam indikator yang telah ditentukan. Metode observasi yang digunakan pada observasi ini adalah metode observasi sistematik dan terstruktur. Panduan observasi dibuat berdasarkan turunan teori yang telah 
ditetapkan. Model pencatatan observasi dilakukan dengan menggunakan Behavior checklist atau pencatatan checklist. Behavior checklist merupakan salah satu teknik pencatatan observasi, dimana pada pencatatan tersebut telah tersedia daftar urutan perilaku atau karakteristik yang hendak diobservasi dan melakukan pencatatan perilaku yang muncul dan tidak dengan tanda cek pada draft yang telah tersedia (Daniels, dkk, 2008).

Tabel 1. Hasil Observasi

\begin{tabular}{|c|c|c|}
\hline No & Aspek & Hasil Observasi \\
\hline & Tingkat (level) & $\begin{array}{l}\text { - Subjek memiliki tingkat keyakinan diri yang tinggi pada } \\
\text { pengerjaan tugas di perkuliahan. Hal tersebut dapat } \\
\text { dilihat dari hasil observasi yang menunjukkan bahwa } \\
\text { sering mendapatkan tugas kuliah. Walau terdapat banyak } \\
\text { kesulitan dalam mengerjakan tugas-tugas tersebut, namun } \\
\text { subjek memiliki keyakinan yang tinggi untuk selalu } \\
\text { mampu mengerjakan tugas tersebut. Banyak usaha yang } \\
\text { dapat dilakukan subjek untuk mengatasi kesulitan, antara } \\
\text { lain aktif melakukan diskusi, pencarian referensi baik itu } \\
\text { melalui internet maupun buku-buku. }\end{array}$ \\
\hline 2. & $\begin{array}{l}\text { Keluasan } \\
\text { (generality) }\end{array}$ & $\begin{array}{l}\text { - Subjek memiliki keyakinan diri yang cukup tinggi } \\
\text { terhadap penguasaan materi dalam bidang yang dijalani. } \\
\text { Hal tersebut nampak pada saat subjek melakukan diskusi } \\
\text { dengan teman-teman. }\end{array}$ \\
\hline
\end{tabular}

2. Hasil wawancara

Tema wawancara pada asesmen ini adalah efikasi diri akademik pada mahasiswa. Wawancara dilakukan tiga kali, kepada subjek, dan 2 significant others, yaitu teman kosan dan teman kelas subjek. Pendekatan wawancara yang dilakukan adalah wawancara semi terstruktur, dimana wawancara dilakukan berdasarkan panduan yang terorganisir dari turunan teori yang telah ditetapkan. Dalam wawancara semi terstruktur ini, interviewer tetap menggali data atau informasi-informasi yang akan memperkuat tujuan wawancara. Panduan wawancara dibuat mengacu pada indikator yang telah ditentukan sesuai dengan aspek dari target perilaku yaitu level, keluasan dan kekuatan. 
Tabel 2. Analisis Hasil Observasi dan Wawancara

\begin{tabular}{|c|c|c|}
\hline Aspek & Observasi & Wawancara \\
\hline Tingkatan & $\begin{array}{l}\text { Subjek memiliki tingkat keyakinan } \\
\text { diri yang tinggi pada pengerjaan } \\
\text { tugas di perkuliahan. Hal tersebut } \\
\text { dapat dilihat dari hasil observasi } \\
\text { yang menunjukkan bahwa sering } \\
\text { mendapatkan tugas kuliah. Walau } \\
\text { terdapat banyak kesulitan dalam } \\
\text { mengerjakan tugas-tugas tersebut, } \\
\text { namun subjek memiliki keyakinan } \\
\text { yang tinggi untuk selalu mampu } \\
\text { mengerjakan tugas tersebut. Banyak } \\
\text { usaha yang dapat dilakukan subjek } \\
\text { untuk mengatasi kesulitan, antara } \\
\text { lain aktif melakukan diskusi, } \\
\text { pencarian referensi baik itu melalui } \\
\text { internet maupun buku-buku }\end{array}$ & $\begin{array}{l}\text { Subjek sering mendapatkan tugas } \\
\text { kuliah namun subjek meyakini bahwa } \\
\text { sesulit apapun tugas tersebut pasti } \\
\text { dapat diselesaikannya. Subjek memiliki } \\
\text { motivasi yang tinggi untuk } \\
\text { menyelesaikan tugas-tugas tersebut. } \\
\text { Dalam menghadapi kesulitan tersebut } \\
\text { subjek melakukan berbagai cara yaitu } \\
\text { aktif berdiskusi dan bertanya kepada } \\
\text { siapapun utamanya teman-teman } \\
\text { apabila terdapat informasi yang tidak } \\
\text { diketahui, aktif mencari referensi di } \\
\text { buku dan internet }\end{array}$ \\
\hline Keluasan & $\begin{array}{l}\text { Subjek memiliki keyakinan diri } \\
\text { yang cukup tinggi terhadap } \\
\text { penguasaan materi dalam bidang } \\
\text { yang dijalani. Hal tersebut nampak } \\
\text { pada saat subjek melakukan diskusi } \\
\text { dengan teman-teman }\end{array}$ & $\begin{array}{l}\text { Subjek yakin untuk menekuni bidang } \\
\text { yang saat ini digeluti karena adanya } \\
\text { motivasi dari pengalaman kerja yang } \\
\text { telah dilalui. Subjek merasa yakin } \\
\text { bahwa ilmu dan pengetahuan yang } \\
\text { dicari selama ini akan dia dapatkan } \\
\text { pada jurusan/bidang ini Walaupun } \\
\text { melanjutkan pendidikan yang tidak } \\
\text { linear dengan sebelumnya, subjek } \\
\text { merasa nyaman dengan bidang yang } \\
\text { saat ini }\end{array}$ \\
\hline Kekuatan & & $\begin{array}{l}\text { Subjek memiliki keyakinan dan } \\
\text { kekuatan bahwa usaha dan } \\
\text { pengorbanan besar yang dilakukannya } \\
\text { sekarang, pasti akan mampu } \\
\text { mewujudkan harapan besar yang telah } \\
\text { diimpikannya. }\end{array}$ \\
\hline
\end{tabular}

Berdasarkan hasil observasi dan wawancara menunjukkan bahwa subjek memiliki bahwa subjek memiliki efikasi diri yang tinggi terhadap bidang ilmu yang dijalani saat ini. Hal tersebut nampak pada keseriusan subjek terhadap materi-materi kuliah dan upaya-upaya subjek dalam menghadapi kesulitan pada tugas-tugas kuliah. Subjek memiliki tingkat keyakinan diri yang tinggi pada pengerjaan tugas di perkuliahan. Hal tersebut dapat dilihat dari hasil observasi yang menunjukkan bahwa sering mendapatkan tugas kuliah. Walau terdapat banyak kesulitan dalam 
mengerjakan tugas-tugas tersebut, namun subjek memiliki keyakinan yang tinggi untuk selalu mampu mengerjakan tugas tersebut. Banyak usaha yang dapat dilakukan subjek untuk mengatasi kesulitan, antara lain aktif melakukan diskusi, pencarian referensi baik itu melalui internet maupun buku-buku.

Selanjutnya pada aspek generality, subjek memiliki keyakinan diri yang cukup tinggi terhadap penguasaan materi dalam bidang yang dijalani. Hal tersebut nampak pada saat subjek melakukan diskusi dengan teman-teman. Salah satu penyebab keyakinan yang kuat tersebut juga muncul karena adanya motivasi dari pengalaman kerja yang telah dilalui. Subjek merasa yakin bahwa ilmu dan pengetahuan yang dicari selama ini akan dia dapatkan pada jurusan/bidang ini. Walaupun melanjutkan pendidikan yang tidak linear dengan sebelumnya, subjek merasa nyaman dengan bidang yang saat ini.

Subjek juga memiliki kekuatan yang sangat besar terhadap keyakinannya bahwa bahwa usaha dan pengorbanan besar yang dilakukannya sekarang, suatu saat akan mampu mewujudkan harapan besar yang telah diimpikannya tersebut.

\section{PENUTUP}

Berdasarkan hasil penelitian menunjukkan bahwa subjek memiliki efikasi diri yang tinggi terhadap bidang ilmu yang dijalani saat ini. Hal tersebut nampak pada keseriusan subjek terhadap materi-materi kuliah dan upaya-upaya subjek dalam menghadapi kesulitan pada tugas-tugas kuliah. Subjek memiliki tingkat keyakinan diri yang tinggi pada pengerjaan tugas di perkuliahan. Bagi subjek walau terdapat banyak kesulitan dalam mengerjakan tugas-tugas tersebut, namun subjek memiliki keyakinan yang tinggi untuk selalu mampu mengerjakan tugas yang diberikan.

\section{DAFTAR PUSTAKA}

Bong, M., Skaalvik, E. M. 2003. Academic self-concept and selfefficacy: How different are they really?. Educational Psychology Review, Vol. 15 (1).

Mulyadi, M. (2011). Penelitian kuantitatif \& kualitatif. Jakarta: Publica Institute.

Pallant, J. (2007). SPSS survival manual a step by step guide to data analysis using SPSS for windows third edition. New York: McGraw Hill Open University Pers.

Papalia, D. E., Olds, S.W., Fieldman, R.D. (2008). Human Development. Jakarta: Salemba Humanika. 
Sattler, J.M. (2002). Assessment for Children: Behavioral and Clinical Application 4th edition. San Diego: Jerome M. Sattler, Publisher Inc.

Schunk, D.H., Pajares, F. (2012). The development of academic selfefficacy. San Diego: Academic Press.

Sugiyono, D.R. (2007). Statistika untuk Penelitian. Bandung: Alfabeta.

Turgut, M. (2013). Academic self-efficacy belief of undergraduate mathematics education students. Acta Didaction Napocensia, Vol. 6 (1). 